\title{
Serum concentration and mRNA expression in milk somatic cells of toll-like receptor 2 , toll-like receptor 4 , and cytokines in dairy cows following intramammary inoculation with Escherichia coli
}

\author{
J. L. Ma, ${ }^{\star 1}$ Y. H. Zhu, ${ }^{\star 1}$ L. Zhang,† Z. Y. Zhuge, ${ }^{\star}$ P. Q. Liu, ${ }^{\star}$ X. D. Yan, ${ }^{*}$ H. S. Gao, ${ }^{\star}$ and J. F. Wang ${ }^{\star 2}$ \\ ${ }^{*}$ College of Veterinary Medicine, China Agricultural University, Beijing 100193, China \\ †Department of Genetics and Biotechnology, Faculty of Agricultural Sciences, University of Aarhus, Blichers Allé 20, 8830 Tjele, Denmark
}

\begin{abstract}
The objective of the current study was to investigate the toll-like receptors (TLR), including the soluble forms sTLR2 and sTLR4, involved in innate immune responses of dairy cows to experimentally induced Escherichia coli mastitis. Six clinically healthy Holstein dairy cows received an intramammary inoculation of E. coli O111:K58 between 63 and 83 d postpartum. Concentrations of sTLR2 and sTLR4, the proinflammatory cytokines IL- 6 and tumor necrosis factor- $\alpha$ $(\mathrm{TNF}-\alpha)$, and acute phase proteins serum amyloid A (SAA) and haptoglobin (Hp) in blood were measured by ELISA. Furthermore, $10 \mathrm{~mL}$ of milk was collected from challenged quarters immediately before inoculation and at $6,12,24,48$, and $72 \mathrm{~h}$ after inoculation, and mRNA expression of selected genes, including TLR2, TLR4, IL-1 $\beta$, IL-6, TNF- $\alpha$, and IL-8, was quantified by real-time PCR. Escherichia coli intramammary infection elicited a decrease in the circulating levels of leukocytes. Rectal temperature was elevated at $6 \mathrm{~h}$ postinoculation (PI). Similarly, the serum concentrations of TNF- $\alpha$, IL-6, and SAA increased at $6 \mathrm{~h}$ PI. However, serum concentrations of sTLR2, sTLR4, and Hp did not differ after challenge. The mRNA expression of TLR2, IL-1 $\beta$, and IL-8 in milk somatic cells increased at $12 \mathrm{~h}$ PI, whereas a decreased IL-6 mRNA expression was detected from 6 to 48 h PI. In conclusion, we found that TLR2 mRNA expression increased in milk somatic cells collected from infected quarters of cows challenged with $E$. coli, whereas the concentrations of sTLR2 and sTLR4 remained unchanged after challenge. Thus, sTLR2 and sTLR4 may protect the host by sequestrating pathogen-associated molecular patterns during E. coli mastitis.
\end{abstract}

Key words: bovine mastitis, cytokine, Escherichia coli, toll-like receptor

Received January 12, 2011.

Accepted August 27, 2011.

${ }^{1}$ These authors contributed equally to this work.

${ }^{2}$ Corresponding author: Jiufeng_wang@hotmail.com

\section{INTRODUCTION}

Bovine mastitis, which is an inflammation of the mammary gland that often develops following intramammary bacterial infection, is one of the most prevalent and economically costly diseases to the dairy industry (Seegers et al., 2003). Gram-negative bacteria are responsible for approximately one-third of all clinical cases of bovine mastitis, and almost $25 \%$ of these cases result in culling or death of the animal (Eberhart, 1984). Among the gram-negative bacteria, Escherichia coli remain the most prevalent cause of clinical mastitis in cows (Wilson et al., 1997).

The innate immune system provides initial protection against $E$. coli infection by detecting the presence of the invading pathogens and mounting an inflammatory response (Akira et al., 2006). Recognition of pathogens is mediated by cellular pattern recognition receptors that recognize pathogen-associated molecular patterns (PAMP; Aderem and Ulevitch, 2000). Toll-like receptors (TLR) comprise a family of pattern recognition receptors that are capable of recognizing distinct PAMP (Hallman et al., 2001). For example, TLR2 recognizes peptidoglycan and lipoteichoic acid from Staphylococcus aureus and other gram-positive bacteria, whereas TLR4 recognizes LPS from gram-negative bacteria, including E. coli (Hoffmann et al., 1999). In cattle, sequences for 10 TLR have been described, and each TLR is capable of recognizing a distinct PAMP (Werling et al., 2006). Expression of both TLR2 and TLR4 mRNA increases in mammary glands of cows with mastitis caused by either Staph. aureus or E. coli (Goldammer et al., 2004). Likewise, an increase in TLR2 mRNA expression was found in infected mammary glands of cows with experimentally induced E. coli mastitis (Petzl et al., 2008). Although most TLR are transmembrane receptors, soluble forms of some TLR (sTLR) have recently been identified in various body fluids and cellular secretions in human (Srinivasan et al., 2008; Dulay et al., 2009; Zunt et al., 2009), although little is known of their role in domestic animals. 
A key component of the host innate immune response to infection is the upregulation of cytokine production (Dinarello, 1996b; Koj, 1996; Suffredini et al., 1999). Cytokines such as tumor necrosis factor- $\alpha$ (TNF- $\alpha$ ), IL-1, and IL-6 mediate the inflammatory response at both the local and systemic levels and are regarded as proinflammatory cytokines (Dinarello, 1996a; Thijs et al., 1996). Locally, these cytokines induce expression of vascular endothelial adhesion molecule, thereby promoting neutrophil transendothelial migration to the site of infection. Systemically, TNF- $\alpha$ and IL-1 $\beta$ are potent inducers of fever and the acute phase response, which is characterized by fever, leukocyte mobilization, and increased production of inflammatory cytokines and acute phase proteins (APP) such as serum amyloid A (SAA), haptoglobin (Hp), and LPS-binding protein (Uthaisangsook et al., 2002). Increases in serum or plasma concentrations of TNF- $\alpha$, IL- $1 \beta$, or IL- 6 have been reported during mastitis in cows (Bannerman et al., 2004). Moreover, previous studies in cows (Lee et al., 2006) have detected significant increases in IL-1 $\beta$, IL-6, IL-8, and TNF- $\alpha$ at both the mRNA and the protein levels in either milk or mammary tissues collected from the infected mammary glands following intramammary inoculation with $E$. coli.

Therefore, the aim of this study was to investigate mRNA expression of TLR2 and TLR4 in milk somatic cells, and their soluble forms sTLR2 and sTLR4 in blood, during innate immune responses of dairy cows to experimentally induced $E$. coli mastitis.

\section{MATERIALS AND METHODS}

\section{Cows}

Six clinically healthy Holstein dairy cows at a commercial dairy herd in Beijing were selected for the study. Cows ( 3 to $4 \mathrm{yr}$ old and 63 to $83 \mathrm{~d}$ postpartum) were free of pathogens through 3 consecutive bacteriological examinations and each had quarter milk SCC $<200,000$ cells/mL $10 \mathrm{~d}$ before the start of the trial. Cows were kept in individual box stalls and fed a mixed ration formulated for the dairy herd. They were milked twice daily at 0700 and $1800 \mathrm{~h}$. Daily milk production of each cow $(\mathrm{kg} / \mathrm{d})$ was measured. The use and care of all animals in this study was approved by the China Laboratory Animal Care and Use Committee.

\section{E. coli Strain}

The E. coli strain O111:K58 (CVCC1450; China Institute of Veterinary Drug Centre, Beijing, China) used for the induction of mastitis (Zhen et al., 2008) was grown in Luria-Bertani broth containing 1\% tryptone,
$0.5 \%$ yeast extract, and $1 \% \mathrm{NaCl}$, at $\mathrm{pH}$ 7.0. Tryptone and yeast extract were from Oxoid (Basingstoke, UK). After overnight incubation at $37^{\circ} \mathrm{C}$ with shaking, bacteria were diluted 1:100 in fresh Luria-Bertani broth. Following incubation, the bacterial cells were harvested by centrifugation at $3,000 \times g$ for $10 \mathrm{~min}$ at $4^{\circ} \mathrm{C}$, washed in sterile physiological saline, and resuspended in saline. Inoculum dose was generated as described in a previous study (Vangroenweghe et al., 2004). A solution of E. coli containing approximately $1 \times 10^{6} \mathrm{cfu} / \mathrm{mL}$ was prepared. Concentrations of $E$. coli were determined by densitometry followed by counts of colony-forming units after agar plating of bacterial serial dilutions.

\section{Experimental Design and Intramammary Challenge}

The teat of the left rear quarter of each cow was carefully washed with soap and disinfected with ethanol 30 min after the morning milking. A blunt cannula was then introduced through the teat canal, and $2 \mathrm{~mL}$ of $E$. coli inoculum was infused.

\section{Blood and Milk Sampling}

Blood samples were taken at the same time points as the milk samples. Blood and milk samples were collected at 0 (just before inoculation), 2, 4, 6, 12, 24, 48, and $72 \mathrm{~h}$ after inoculation with $E$. coli. Blood was collected via jugular venipuncture into glass tubes that contained either no additive or EDTA as an anticoagulant, which allowed us to obtain serum and plasma, respectively. Blood samples were centrifuged $(2,000 \times g$ for $30 \mathrm{~min}$ at $0^{\circ} \mathrm{C}$ ) and the plasma and serum were stored at $-80^{\circ} \mathrm{C}$ until subsequent analysis. Serum was separated for later quantification of cytokines, APP, and sTLR. Blood sampled with EDTA was used for leukocyte analysis. Ten milliliters of milk from each quarter was collected aseptically for bacteriology and SCC determinations. Total milk was then collected from each quarter immediately before inoculation and at $6,12,24,48$, and $72 \mathrm{~h}$ after inoculation. All samples were kept on melting ice $\left(1^{\circ} \mathrm{C}\right)$ during transport and at the laboratory until analyses were performed or aliquots were prepared for freezing. Milk samples collected were immediately used for RNA extraction and reverse transcription.

\section{Analytical Methods for Indicators of Inflammation}

The number of E. coli $(\mathrm{cfu} / \mathrm{mL})$ after experimental inoculation was determined by appropriate 10 -fold dilutions of each milk sample in sterile saline. Ten microliters of each dilution was plated on eosin methylene blue agar (Oxoid), and all dilutions were performed in duplicate. Colonies were counted after $24 \mathrm{~h}$ of in- 
cubation at $37^{\circ} \mathrm{C}$. The colony count was converted to colony-forming units per milliliter based on the factor of dilution and expressed as $\log _{10} \mathrm{cfu} / \mathrm{mL}$ for statistical analysis. Milk SCC was determined using a cell counter (C-Reader System model ADAM, Digital Bio Technology Inc., Seoul, Korea).

Total white blood cell counts were determined using an automated hematology analyzer (Celltac $\alpha$, Nihon Kohden, Tokyo, Japan) calibrated for bovine blood. Differential leukocyte counts were estimated by staining of blood smears with May-Grünwald-Giemsa stain and by sequentially counting 200 cells under a microscope using 50 -fold magnification.

Serum concentrations of IL-6, TNF- $\alpha$, and cortisol were determined in duplicate using commercially available bovine ELISA kits (RapidBio Lab, West Hills, CA) with sensitivities of $30 \mathrm{pg} / \mathrm{mL}, 5 \mathrm{pg} / \mathrm{mL}$, and $5 \mathrm{ng} /$ $\mathrm{mL}$, respectively. Serum concentrations of SAA and Hp were determined in duplicate using commercially available bovine ELISA kits (ESB Laboratory, Sacramento, CA) with sensitivities of $0.5 \mu \mathrm{g} / \mathrm{mL}$ and $0.12 \mu \mathrm{g} / \mathrm{mL}$, respectively. Soluble TLR2 and sTLR4 were quantified by using biotin-conjugated polyclonal antibody preparations specific for the quantitative determination of bovine TLR2 and TLR4 concentrations in serum and plasma using commercially available ELISA kits (ESB Laboratory) with sensitivities of $0.39 \mathrm{ng} / \mathrm{mL}$ and 0.39 $\mathrm{ng} / \mathrm{mL}$, respectively.

\section{Milk Somatic Cell Isolation and Viability Test}

Milk somatic cell isolation and viability tests were carried out as described previously (Lee et al., 2006) with modifications. Aseptically collected milk samples were diluted 1:1 with cold $\left(4^{\circ} \mathrm{C}\right)$ sterile PBS $(\mathrm{pH} 7.4)$ and centrifuged $\left(1,000 \times g\right.$ for $20 \mathrm{~min}$ at $\left.4^{\circ} \mathrm{C}\right)$. The fat layer and supernatant were removed and the cell pellet was resuspended and centrifuged twice in PBS $(400 \times$ $g$ and $300 \times g$ for $10 \mathrm{~min}$ at $4^{\circ} \mathrm{C}$ ). The final pellet was resuspended in cold PBS (1 to $50 \mathrm{~mL}$, depending on the original total cell concentration, to obtain an optimal cell concentration for differentiation). The cell suspension was used for determining the cell count and viability in a Neubauer counting chamber with direct light microscopy using Trypan blue staining (1:1 dilution). Viable cells appeared shining white under the microscope, whereas dead cells appeared blue.

\section{RNA Extraction and Reverse Transcription}

Total RNA extraction was performed using Trizol (Invitrogen, Carlsbad, CA) according to the manufacturer's instructions. The optical density at 260:280 ratio of samples was measured with a NanoDrop ND-
1000 Spectrophotometer (NanoDrop Technologies Inc., Wilmington, DE) to determine the quality of extracted RNA, and the integrity was analyzed by agarose gel electrophoresis through staining with ethidium bromide and visualization under UV light. The RNA was then reversed transcribed into cDNA using the ImProm-II Reverse Transcription Kit (Promega, Madison, WI) according to the manufacturer's instructions. The reverse transcription (RT) reaction was started by adding $2 \mu \mathrm{g}$ of total RNA and $0.5 \mu \mathrm{g}$ of oligo $\left(\mathrm{dT}_{15}\right)$ to $12.5 \mu \mathrm{L}$ of sterile, distilled water and heating at $72^{\circ} \mathrm{C}$ for $5 \mathrm{~min}$. After cooling on ice, $10 \mathrm{~m} M$ dithiothreitol (DTT), 0.5 $\mathrm{m} M$ of each dNTP, $5 \times$ first-strand buffer, and $200 \mathrm{U}$ of Superscript II RNase H-Reverse Transcriptase were added. The mixture was stabilized at $25^{\circ} \mathrm{C}$ for $10 \mathrm{~min}$ and subsequently incubated at $42^{\circ} \mathrm{C}$ for 60 min for the $\mathrm{RT}$ reaction. Thereafter, the temperature was increased to $70^{\circ} \mathrm{C}$ for $15 \mathrm{~min}$ to inactivate the reverse transcriptase. Synthesized cDNA was kept at $-20^{\circ} \mathrm{C}$ until further analysis.

\section{Lightcycler Real-Time PCR}

Briefly, the Lightcycler real-time PCR was carried out as described previously (Griesbeck-Zilch et al., 2008) with modifications. Primers for specific bovine genes, as listed in Table 1, were synthesized (Sangon, Shanghai, China) to have an equal annealing temperature of $60^{\circ} \mathrm{C}$. The reaction conditions for each individual gene were optimized using a QuantiTect SYBR Green PCR kit (Tiangen, Beijing, China) in the ABI 7500 RealTime PCR System (Applied Biosystem, Foster City, $\mathrm{CA}$ ) and applied to the following protocol. The cDNA was analyzed in a $20-\mu \mathrm{L}$ PCR mixture containing a final concentration of $0.5 \mu M$ primer, $2 \mu \mathrm{L}$ of cDNA, $10 \mu \mathrm{L}$ of $2 \times$ SYBR Premix DimerEraser, and $0.4 \mu \mathrm{L}$ of ROX (passive reference dye). The PCR mixture was added to a cold PCR capillary, centrifuged, and placed into the LightCycler system. The LightCycler was programmed in 4 steps: (1) denaturation at $95^{\circ} \mathrm{C}$ for $30 \mathrm{~s}$; (2) amplification for 45 cycles of denaturation at $95^{\circ} \mathrm{C}$ for $5 \mathrm{~s}$, annealing at $55^{\circ} \mathrm{C}$ for $30 \mathrm{~s}$, and extension at $72^{\circ} \mathrm{C}$ for $1 \mathrm{~min}$; (3) melting curve by $95^{\circ} \mathrm{C}$ for $15 \mathrm{~s}, 60^{\circ} \mathrm{C}$ for $1 \mathrm{~min}$, and $95^{\circ} \mathrm{C}$ for $30 \mathrm{~s}$; (4) cooling at $40^{\circ} \mathrm{C}$. In each reaction, the cycle number at which the fluorescence rose appreciably above the background fluorescence was determined to be the crossing point (cycle threshold or $\mathbf{C}_{\mathbf{T}}$ value).

\section{Data Analysis of Real-Time PCR}

To evaluate the relative quantification of mRNA expression, the $\mathrm{C}_{\mathrm{T}}$ values of the target genes were normalized against the arithmetic mean (AM) of 3 reference 
Table 1. Sequences and accession numbers of oligonucleotide primers used for real-time PCR and the length of the PCR products ${ }^{1}$

\begin{tabular}{|c|c|c|c|c|}
\hline Gene $^{2}$ & Forward/reverse & $\begin{array}{l}\text { Oligonucleotide sequences } \\
\left(5^{\prime} \text { to } 3^{\prime}\right) \text { of primers }\end{array}$ & $\begin{array}{l}\text { GenBank } \\
\text { accession no. }\end{array}$ & $\begin{array}{l}\text { Product } \\
\text { length (bp) }\end{array}$ \\
\hline \multirow[t]{2}{*}{ GAPDH } & $\mathrm{F}$ & GTC TTC ACT ACC ATG GAG AAG G & \multirow[t]{2}{*}{ NM001034034 } & \multirow[t]{2}{*}{201} \\
\hline & $\mathrm{R}$ & TCA TGG ATG ACC TTG GCC AG & & \\
\hline YWHAZ & $\mathrm{R}$ & GAC CCT CCA AGA TGA CCT AC & BC102382 & 141 \\
\hline \multirow[t]{2}{*}{ Ubiquitin } & $\mathrm{F}$ & AGA TCC AGG ATA AGG AAG GCA T & \multirow[t]{2}{*}{ NM174133 } & \multirow[t]{2}{*}{198} \\
\hline & $\mathrm{R}$ & GCT CCA CTT CCA GGG TGA T & & \\
\hline IL-6 & $\mathrm{R}$ & GCT TCA GGA TCT GGA TCA GTG & NM173923 & 215 \\
\hline \multirow[t]{2}{*}{ IL-8 } & $\mathrm{F}$ & ACA CAT TCC ACA CCT TTC CAC & \multirow[t]{2}{*}{ AF232704 } & \multirow[t]{2}{*}{149} \\
\hline & $\mathrm{R}$ & ACC TTC TGC TCC CAC TTT TC & & \\
\hline \multirow[t]{2}{*}{ TNF- $\alpha$} & $\mathrm{F}$ & CCA CGT TGT AGC CGA CAT C & \multirow[t]{2}{*}{ NM173966 } & \multirow[t]{2}{*}{155} \\
\hline & $\mathrm{R}$ & CCC TGA AGA GGA CCT GTG AG & & \\
\hline TLR2 & $\mathrm{F}$ & CAT TCC CTG GCA AGT GGA TTA TC & AY364629 & 201 \\
\hline
\end{tabular}

${ }^{1}$ Griesbeck-Zilch et al. (2008).

${ }^{2} \mathrm{YWHAZ}=$ tyrosine 3-monooxygenase/tryptophan 5-monooxygenase activation protein; TNF- $\alpha=$ tumor necrosis factor- $\alpha$; TLR $=$ toll-like receptor.

genes: GAPDH, ubiquitin, and tyrosine 3-monooxygenase/tryptophan 5-monoxygenase activation protein, and the results were presented as $-\Delta \Delta \mathrm{C}_{\mathrm{T}}$ values (Livak and Schmittgen, 2001). The relative mRNA expression of the target gene at each time point was calculated using the following equation:

$$
\begin{gathered}
\Delta \mathrm{C}_{\mathrm{T}}=\mathrm{C}_{\mathrm{T} \text { (target gene) }}-\mathrm{C}_{\mathrm{T} \text { (AM of housekeeping genes); }} \\
\Delta \Delta \mathrm{C}_{\mathrm{T}}=\Delta \mathrm{C}_{\mathrm{T} \text { (time } \mathrm{X})}-\Delta \mathrm{C}_{\mathrm{T} \text { (time } 0)} .
\end{gathered}
$$

\section{Statistical Analysis}

All statistical evaluations were conducted by use of the SPSS statistical software, version 16.0 (SPSS Inc., Chicago, IL). Data were analyzed by ANOVA for repeated measures. Differences between means were compared with a paired $t$-test. A $P$-value of $<0.05$ was considered statistically significant.

\section{RESULTS}

\section{Clinical Signs After Challenge}

All inoculated cows developed fever $\left(>39.5^{\circ} \mathrm{C}\right)$ within the first $9 \mathrm{~h}$, and maximal values $\left(39.9 \pm 0.4^{\circ} \mathrm{C}\right)$ occurred between 6 and $9 \mathrm{~h}$ after inoculation (Figure $1 \mathrm{~A})$. This was accompanied by a significant decrease in leukocyte counts $8 \mathrm{~h}$ after E. coli inoculation (Figure 1B). Daily milk production decreased by $33.6 \%$ (data not shown) on the first day after challenge, and the 6 cows remained significantly depressed until 6 d post- inoculation (PI). Abnormal milk with clots or flakes from challenged quarters was present in all the cows during the second and third days after challenge. Milk SCC of uninfected quarters in the 6 cows was below 5 $\times 10^{5}$ cells $/ \mathrm{mL}$ throughout the study. Within $6 \mathrm{~h}$ of inoculation, milk SCC of E. coli-infected quarters rapidly exceeded $1 \times 10^{7}$ cells $/ \mathrm{mL}$ (data not shown) in 3 of the cows, and remained at this level until $96 \mathrm{~h} \mathrm{PI}$, and then decreased to around $1 \times 10^{6}$ cells $/ \mathrm{mL}$ at the end of the study at $168 \mathrm{~h}$. Udder parameters, such as swelling and elevated quarter temperature, appeared from $6 \mathrm{~h}$ after inoculation in the infected quarters. The number of $E$. coli in the infected quarters peaked at $6 \mathrm{~h}$ after inoculation, followed by a rapid clearance within $12 \mathrm{~h}$.

\section{Cytokines, APP, and TLR in Blood}

Serum IL-6 concentrations were significantly elevated from $4 \mathrm{~h}(P=0.013)$ to $12 \mathrm{~h}(P=0.022)$ and peaked at $6 \mathrm{~h}(P<0.001)$ after inoculation, then gradually decreased to the preinoculation levels (Figure 2A). Serum TNF- $\alpha$ concentrations were significantly elevated from $4(P=0.023)$ to $12 \mathrm{~h}(P=0.046)$, peaked at 6 $\mathrm{h}(P=0.004) \mathrm{PI}$, and then gradually decreased to the preinoculation level (Figure 2B).

Serum SAA concentrations were significantly elevated from $6(P<0.001)$ to $12 \mathrm{~h}(P=0.048)$ and peaked at $6 \mathrm{~h}$ after inoculation (Figure $2 \mathrm{C}$ ). Serum Hp concentrations decreased significantly at $48 \mathrm{~h}(P=0.05)$ and $168 \mathrm{~h}(P=0.18)$ after inoculation compared with 0 $\mathrm{h}$ (Figure 2D). However, the concentrations of serum cortisol were unaltered (data not shown). Concentra- 

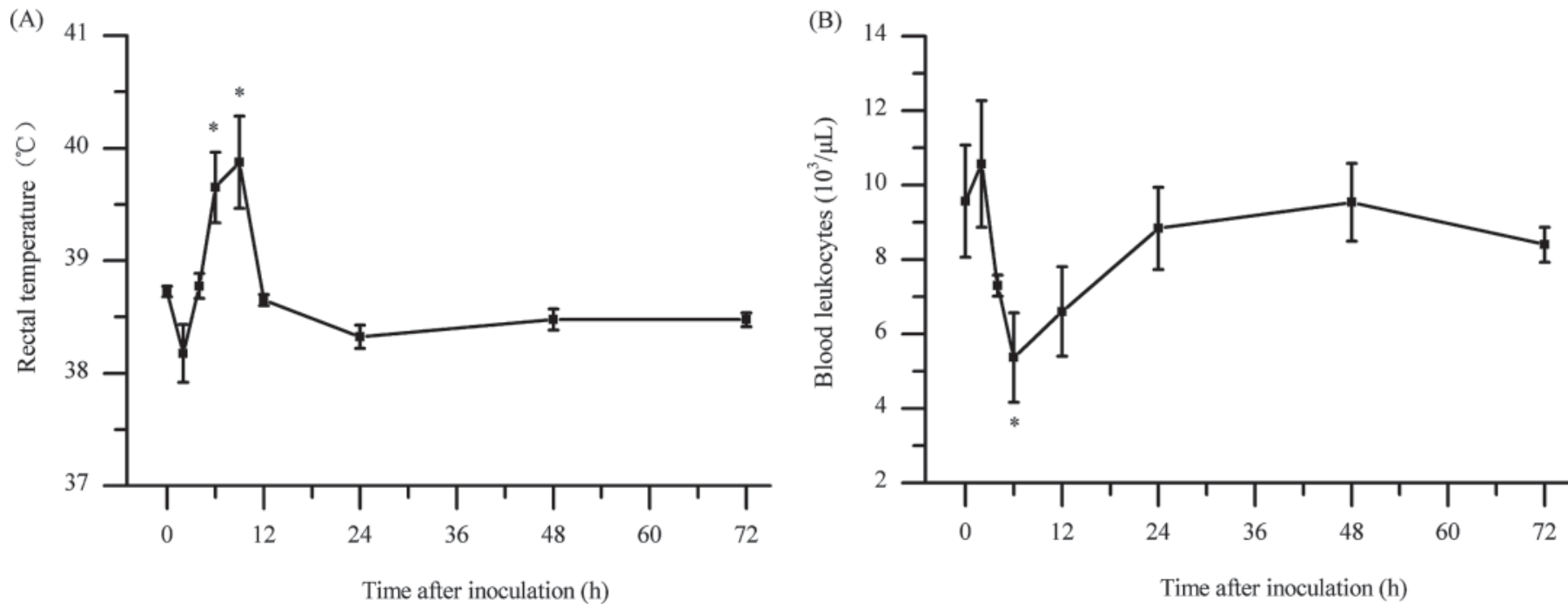

Figure 1. Rectal temperature (A) and leukocytes in blood (B) in dairy cows following intramammary inoculation with Escherichia coli. Values are means of 6 observations with the standard error of means represented by vertical bars. Values differ significantly $(* P<0.05)$ from $0 \mathrm{~h}$.

tions of serum sTLR2 and sTLR4 after inoculation did not differ relative to the preinoculation levels (Figure $3 \mathrm{~A}$ and $\mathrm{B})$.

\section{mRNA Expression of TLR and Cytokines in Milk Somatic Cells}

Intramammary inoculation of $E$. coli caused an increase in TLR2 mRNA expression (Figure 4A); expression increased significantly at $12 \mathrm{~h}(P<0.001)$ and $24 \mathrm{~h}$ $(P<0.05)$ and decreased at $48 \mathrm{~h}$ and $72 \mathrm{~h}$ PI. However, TLR4 mRNA expression did not differ relative to the preinoculation level during the observed period (Figure $4 \mathrm{~B})$.

Expression of IL-1 $\beta$ mRNA was significantly elevated at $6 \mathrm{~h}(P<0.01)$ and $12 \mathrm{~h}(P<0.001)$, and peaked at $12 \mathrm{~h}$ with a slight decrease at $48 \mathrm{~h}$ and $72 \mathrm{~h}$ PI (Figure $5 \mathrm{~A})$. Similarly, expression of TNF- $\alpha$ mRNA increased significantly at $12 \mathrm{~h}(P<0.01)$ and $24 \mathrm{~h}(P<0.001)$ PI (Figure 5D). Expression of IL- 8 mRNA showed a significant increase at $12 \mathrm{~h}(P<0.05)$ and $24 \mathrm{~h}(P<$ $0.01)$ and a decrease at $48 \mathrm{~h}$ and $72 \mathrm{PI}$ compared with the preinoculation level (Figure 5C). However, IL-6 mRNA expression decreased in the observation period and then gradually increased at $48 \mathrm{~h} \mathrm{PI}$ (Figure 5B).

\section{DISCUSSION}

Intramammary infection with $E$. coli elicited a systemic response characterized by the induction of fever and a localized response characterized by proinflammatory cytokine production and elevated milk SCC. The clinical symptoms, metabolism changes, and APP and inflammatory cytokine profiles in blood and mam- mary glands have been previously shown in cows with experimentally induced E. coli mastitis (Bannerman et al., 2004). At the present time, however, the role of TLR and soluble mediators of the early inflammatory response in the mammary gland of the cow is not known. The present study investigated TLR2 and TLR4 mRNA expression in milk somatic cells and their soluble forms sTLR2 and sTLR4 in blood during innate immune responses of dairy cows to experimentally induced E. coli mastitis.

Increases in the concentration of the proinflammatory cytokine TNF- $\alpha$, a potent inducer of fever, in blood were observed from 4 to $12 \mathrm{~h}$ and peaked at $6 \mathrm{~h}$ after infection, a time that was temporally coincident with maximal increases in body temperature. Similarly, increases in serum IL-6 concentration were observed within $12 \mathrm{~h}$ of $E$. coli infection and were temporally coincident with increases in serum SAA concentrations. The induction of a systemic response reported here, as well as the temporal changes in Hp and leukocytes in blood, was consistent with previous studies on bovine mastitis (Eckersall et al., 2001; Bannerman et al., 2004; Gronlund et al., 2005).

Sensing the presence of bacteria in the lumen of the mammary gland is an important step in innate immunity. Milk somatic cells provide an important link between the external environment and the body interior because they are able to recognize conserved molecular patterns of invading microorganisms via pattern recognition receptors, including TLR (Rainard and Riollet, 2006). Escherichia coli is a species of gram-negative bacteria that is expected to upregulate only TLR4. Toll-like receptor 4 has been identified as the pattern recognition receptor for LPS that initiates the PAMP 
(A)

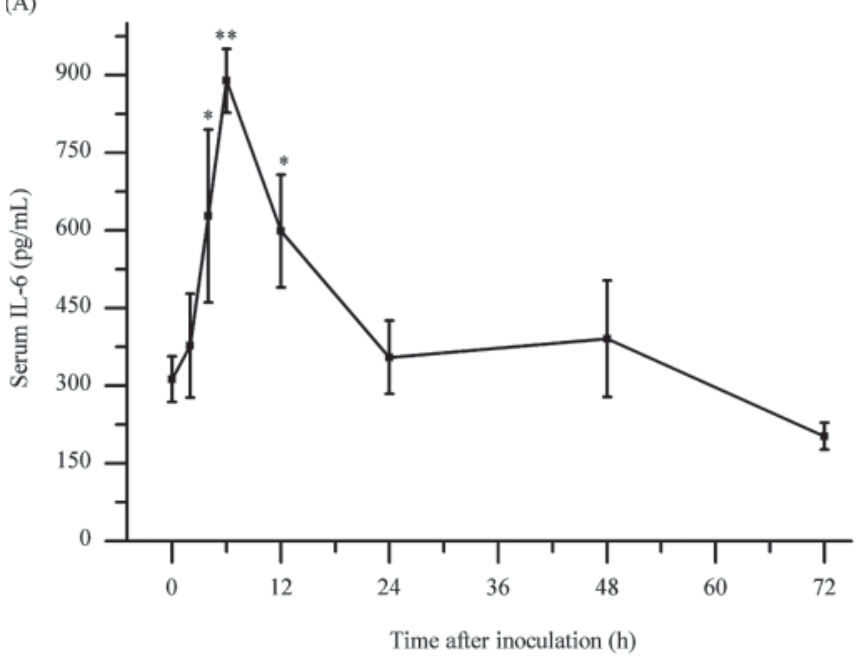

(C)

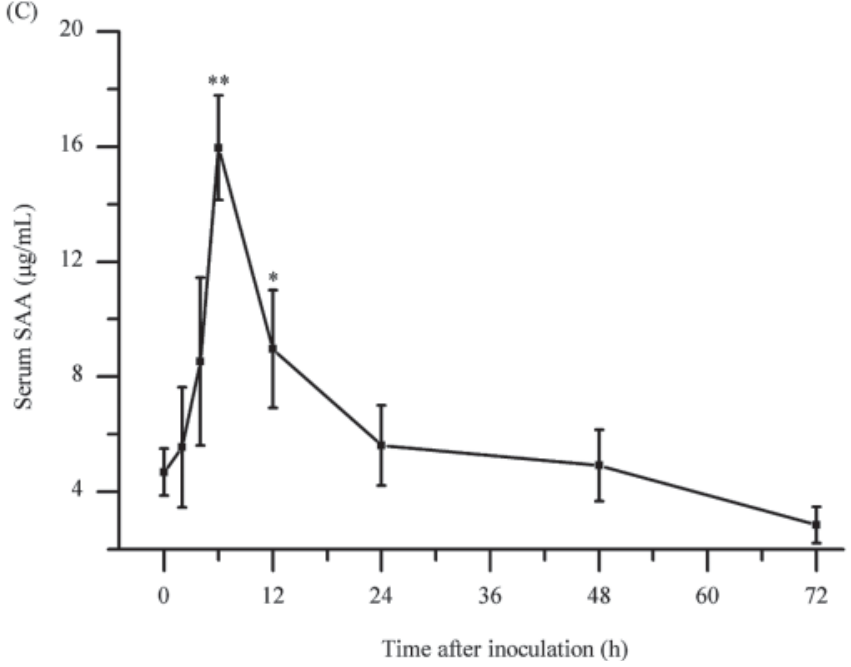

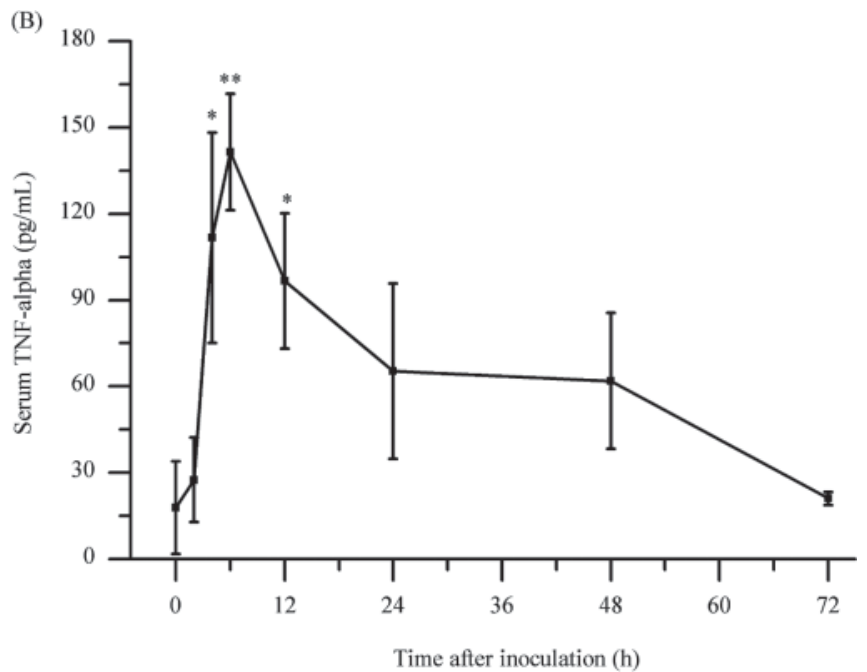

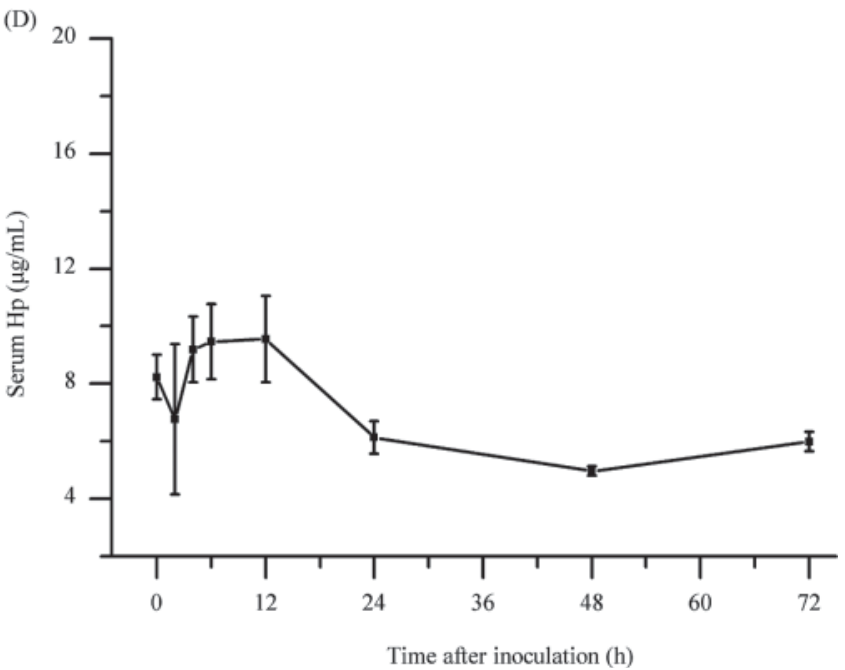

Figure 2. Serum IL-6, tumor necrosis factor- $\alpha$ (TNF- $\alpha$ ), serum amyloid A (SAA), and haptoglobin (Hp) concentrations in dairy cows following intramammary inoculation with Escherichia coli. Values differ significantly $(* P<0.05 ; * * P<0.01)$ from $0 \mathrm{~h}$.

from gram-negative bacteria (Akira and Takeda, 2004). However, a previous study has shown that expression of both TLR2 and TLR4 mRNA increased in mammary glands of cows infected with mastitis caused by either Staph. aureus or E. coli (Goldammer et al., 2004). It was somewhat unexpected that no increase in TLR4 mRNA expression was found in milk somatic cells collected from infected quarters in the current study. Our data are inconclusive regarding the effects of $E$. coli infection, as well as effects of normal lactation, on TLR4.

Interestingly, an increase in TLR2 mRNA expression was found in milk somatic cells collected from infected quarters of cows challenged with $E$. coli. This is in accordance with previous studies in which upregulated expression of TLR2 mRNA was observed in mammary glands challenged with LPS (Ibeagha-Awemu et al., 2008) as well as with E. coli (Yang et al., 2008). It has been shown that mRNA expression of TLR2 and TLR4 was higher in mammary epithelial cells collected from infected quarters of cows challenged with $E$. coli relative to those infected with Staph. aureus (Yang et al., 2008); this result suggests better pathogen recognition of gram-negative bacteria and more effective activation of the immune response, resulting in a severe but not chronic form of mastitis. Taken together, these findings may point to as-yet unknown factors in the mammary gland that would facilitate recognition of microbial products (whether from gram-negative or gram-positive bacteria) by both TLR4 and TLR2.

Although most TLR are transmembrane receptors, soluble forms of some sTLR have recently been identified in amniotic fluid and saliva in humans (Dulay et al., 2009; Zunt et al., 2009). The soluble form of TLR2, sTLR2, is produced by posttranslational modification of the anchored TLR2 that is constitutively expressed in blood monocytes and found in human plasma and 

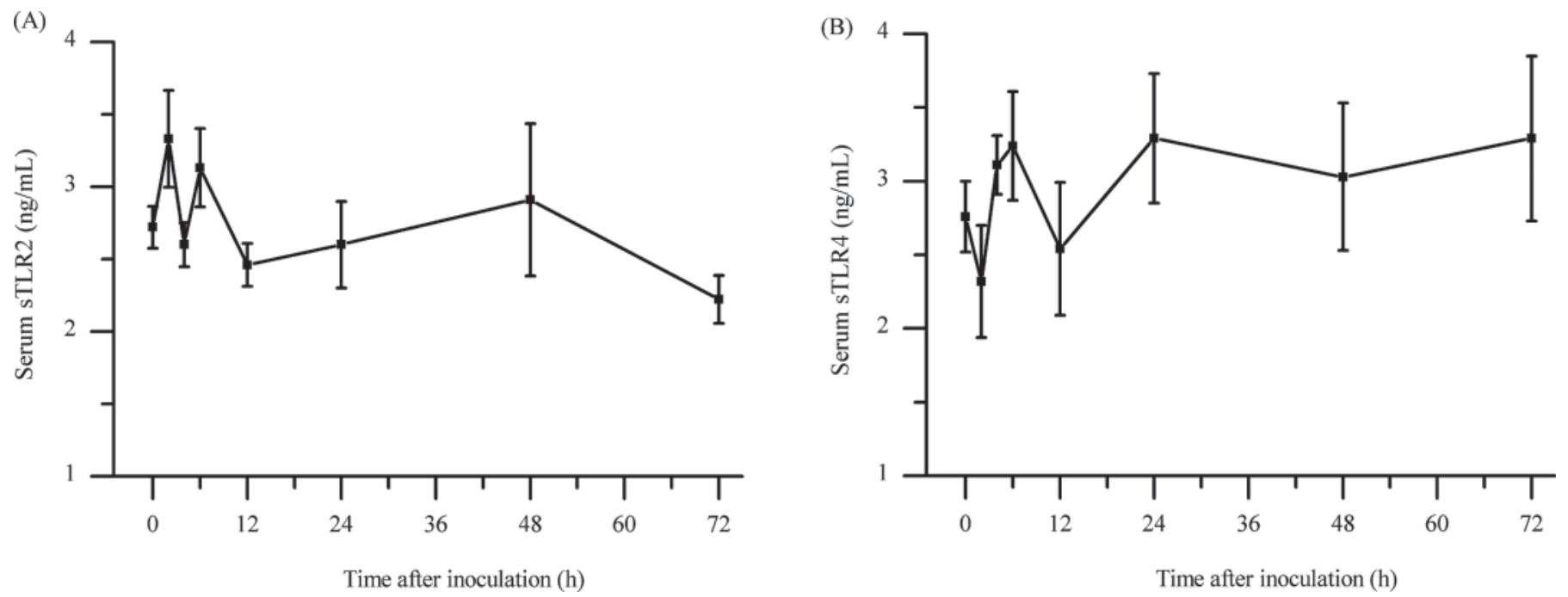

Figure 3. Serum soluble toll-like receptor (sTLR)2 (A) and sTLR4 (B) concentrations in dairy cows following intramammary inoculation with Escherichia coli. Values are means of 6 observations with the standard error of means represented by vertical bars.

milk (LeBouder et al., 2003). The soluble form of TLR4 is an alternative splice variant of TLR4 that was shown to be expressed as a mechanism to inhibit LPS-mediated TNF- $\alpha$ production and nuclear factor $\kappa \mathrm{B}$ activation (Iwami et al., 2000). Some sTLR are potential biomarkers for infectious disease in humans (Dulay et al., 2009). Plasma sTLR may originate from both monocytes and neutrophils (Kurt-Jones et al., 2002; LeBouder et al., 2003), and sTLR were proposed to be produced from the conversion of cell-surface TLR, which is consistent with conversion of CD14 into soluble CD14 (Durieux et al., 1994). This process involves endocytosis of the cell surface receptor and conversion into sTLR by processing in an internal acidic compartment and subsequent release by exocytosis. Cell activation resulted in a rapid

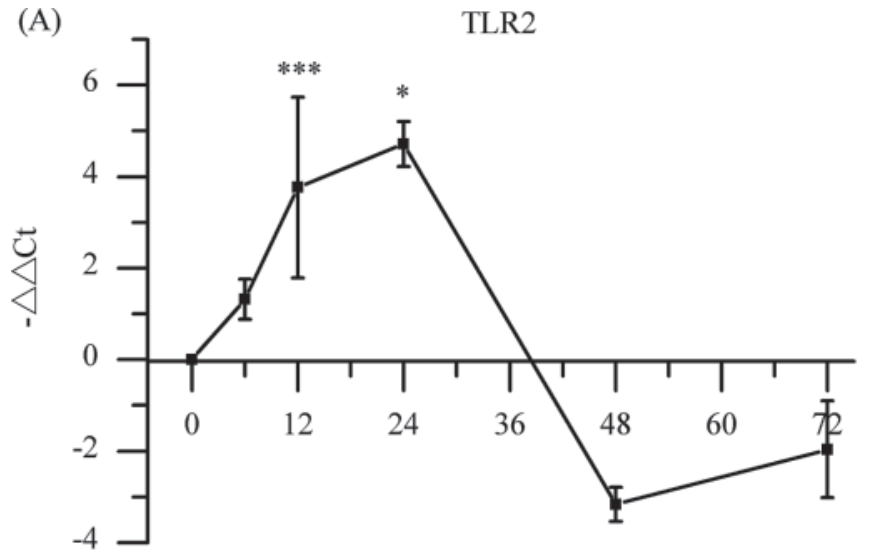

Time after inoculation (h) down-modulation of cell-surface TLR and a similar fast release of sTLR (LeBouder et al., 2003). Soluble TLR were thought to function as decoy receptors to sequestrate circulating PAMP (Srinivasan et al., 2008; Dulay et al., 2009; Zunt et al., 2009). Recombinant TLR attenuate TLR-mediated cellular activation (Iwami et al., 2000; LeBouder et al., 2003; Hyakushima et al., 2004). Relatively stable concentrations of sTLR2 (2.641 $\pm 0.22 \mathrm{ng} / \mathrm{mL})$ and sTLR4 $(2.94 \pm 0.39 \mathrm{ng} / \mathrm{mL})$ were detected in our study, but these results have not been verified by other recent studies in dairy cows. It was reported that cell sensitivity increases when the amount of sTLR in serum decreases, which suggests that serum sTLR may contribute to the regulation, and thus the efficiency, of the innate immune response to invading

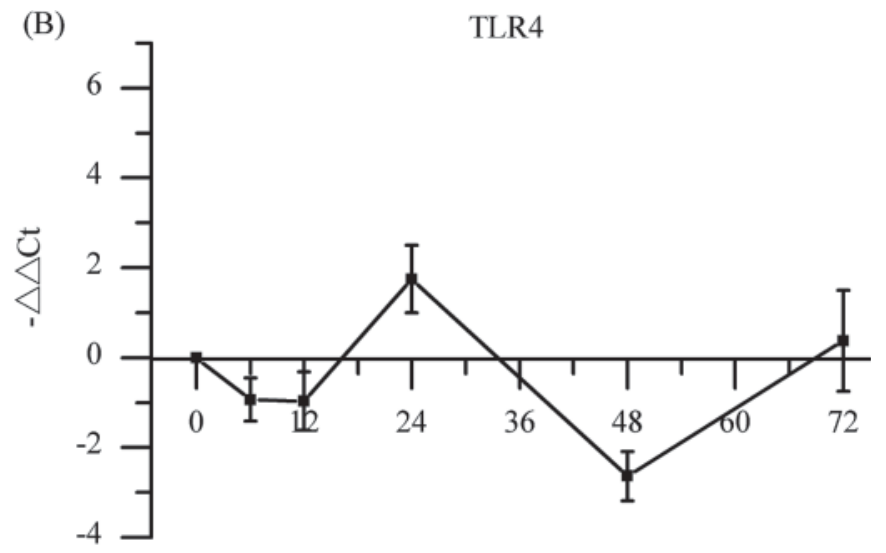

Time after inoculation (h)

Figure 4. Expression of toll-like receptor (TLR) 2 and TLR4 mRNA in milk somatic cells collected from dairy cows following intramammary inoculation with Escherichia coli. Data are means of 6 observations with the standard error of means represented by vertical bars. Values differ significantly $\left({ }^{*} P<0.05 ;{ }^{* * *} P<0.001\right)$ from $0 \mathrm{~h}$. 

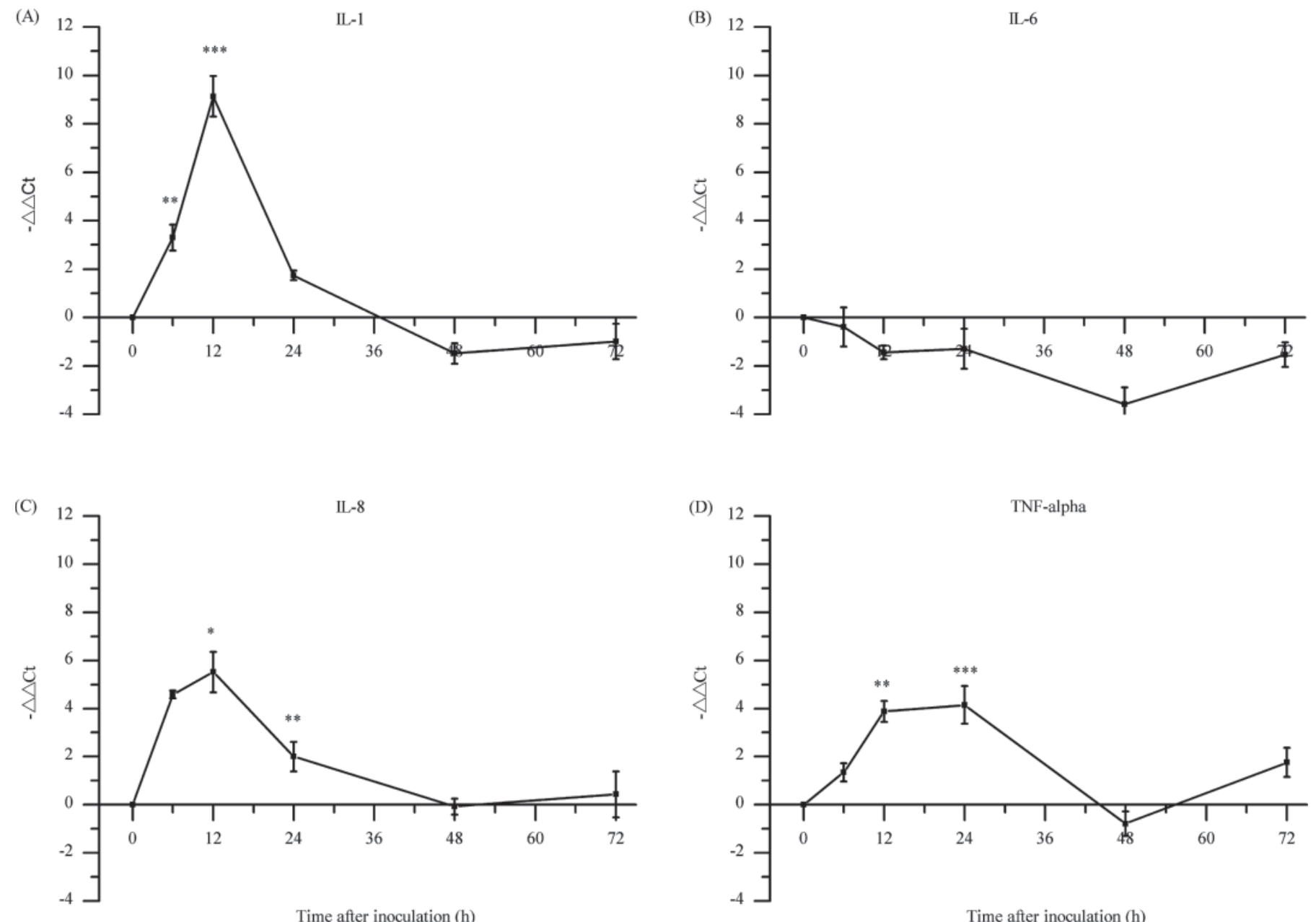

Figure 5. Expression of IL-1, IL-6, IL-8, and tumor necrosis factor- $\alpha$ (TNF- $\alpha$ ) mRNA in milk somatic cells collected from dairy cows following intramammary inoculation with Escherichia coli. Data are means of 6 observations with the standard error of means represented by vertical bars. Values differ significantly $\left(* P<0.05 ;{ }^{* *} P<0.01 ;{ }^{* * *} P<0.001\right)$ from $0 \mathrm{~h}$.

pathogens (LeBouder et al., 2003). Relatively stable amounts of sTLR2 and sTLR4 reported in the present study suggest that sTLR2 and sTLR4 might protect the host by sequestrating PAMP, thus avoiding excess proinflammatory response during $E$. coli mastitis.

During mastitis, changes in IL-1 $\beta$, IL-6, and TNF- $\alpha$, as well as other cytokines such as IL-8, have been well characterized systemically and locally (Lee et al., 2006; Griesbeck-Zilch et al., 2008; Petzl et al., 2008). Systemically, these cytokines are known to induce an acute phase reaction associated with fever and production of APP, and they could be used as markers for subclinical coliform mastitis in cows (Nielsen et al., 2004). Locally, the source of these cytokines is mainly from resident cells within the mammary gland, including epithelial cells and macrophages. These cell types in the mammary gland could rapidly produce an array of cytokines and other inflammatory mediators that mediate inflammation, including IL-1 $\beta$, IL-6, TNF- $\alpha$, and IL-8 (Al- luwaimi et al., 2003). Furthermore, neutrophils, which are recruited to the mammary gland and constitute the majority of the somatic cells in the mammary gland during mastitis, could also release these cytokines (Lee et al., 2006; Baumert et al., 2009).

Many of the biological effects of IL-1 on host innate immune responses to infection are similar to those of TNF- $\alpha$, including activation of endothelial cells and leukocytes and systemic induction of fever and APP synthesis (Dinarello, 1996b; Pruitt et al., 1995). Increases in IL-1 expression during bovine mastitis have been most frequently characterized in experimental $E$. coli intramammary infections. In the present study, an increase in IL-1 $\beta$ mRNA expression was observed in milk somatic cells isolated from quarters infected with E. coli, in accordance with previous studies in which IL-1 $\beta$ is upregulated at the mRNA level in cells isolated from cows with mastitis (Riollet et al., 2001; Peli et al., 2003) and in bovine mammary epithelial cells exposed 
to $E$. coli or $E$. coli-derived products in vitro (McClenahan et al., 2005; Pareek et al., 2005; Strandberg et al., 2005; Lahouassa et al., 2007).

Tumor necrosis factor- $\alpha$ is a highly proinflammatory cytokine with both beneficial and injurious properties (van der Poll and Lowry, 1995). In accordance with our results, previous studies have shown that TNF- $\alpha$ increased at both the protein level in blood and mRNA level in milk somatic cells collected from cows with experimentally induced E. coli mastitis (Blum et al., 2000; Lee et al., 2006). Experimental infection with a lower inoculum $\left(10^{4} \mathrm{cfu} /\right.$ quarter $)$ of $E$. coli has been reported to result in the detection of TNF- $\alpha$ concentrations between 0.1 and $10 \mathrm{ng} / \mathrm{mL}$ in blood (Hirvonen et al., 1999; Hoeben et al., 2000).

Interleukin-6 is a pleiotropic cytokine with both proand antiinflammatory properties. Among the clearly defined antiinflammatory properties of IL-6 is its ability to inhibit expression of IL- $1 \beta$ and TNF- $\alpha$ and to stimulate expression of IL-1-receptor antagonist and soluble TNF receptor (Moshage, 1997; Papanicolaou et al., 1998). Although TNF- $\alpha$ and IL-1 $\beta$ also induce hepatic APP synthesis, evidence exists that IL-6 induces the upregulation of a different set of APP (Moshage, 1997). Interestingly, an elevated concentration of serum IL-6 was detected, which is in accordance with previous studies in cows (Hagiwara et al., 2001). In the present study, however, IL-6 mRNA expression was markedly reduced in cells isolated from quarters infected with $E$. coli.

Interleukin- 8 is chemotactic cytokine that is upregulated in response to infection (Kobayashi, 2008). Previous studies have shown that IL-8 mRNA expression increases in infected mammary glands compared with healthy glands during E. coli mastitis (Vangroenweghe et al., 2005; Lee et al., 2006). Similarly, an increase in IL-8 mRNA expression in milk somatic cells isolated from E. coli-infected glands was confirmed in our study.

\section{CONCLUSIONS}

To our knowledge, the present report is the first study to evaluate soluble forms of TLR2 and TLR4 in blood during $E$. coli-induced mastitis. We found that expression of TLR2 mRNA increased in milk somatic cells collected from infected quarters of cows challenged with E. coli, whereas the concentrations of sTLR2 and sTLR4 remained unchanged after challenge. Based on the present findings, we conclude that currently unknown factors in the mammary gland likely facilitate recognition of microbial products by both TLR4 and TLR2, and that sTLR2 and sTLR4 may protect the host by sequestrating PAMP during E. coli mastitis.

\section{ACKNOWLEDGMENTS}

This project was supported by grants from the Program for New Century Excellent Talents in University (China; Project No. NCET-08-0816), the National Natural Science Foundation of China (Project No. 30972232), and the National Key Program of China (Project No. 2008ZX08008-005).

\section{REFERENCES}

Aderem, A., and R. J. Ulevitch. 2000. Toll-like receptors in the induction of the innate immune response. Nature 406:782-787.

Akira, S., and K. Takeda. 2004. Toll-like receptor signalling. Nat. Rev. Immunol. 4:499-511.

Akira, S., S. Uematsu, and O. Takeuchi. 2006. Pathogen recognition and innate immunity. Cell 124:783-801.

Alluwaimi, A. M., C. M. Leutenegger, T. B. Farver, P. V. Rossitto, W. L. Smith, and J. S. Cullor. 2003. The cytokine markers in Staphylococcus aureus mastitis of bovine mammary gland. J. Vet. Med. B Infect. Dis. Vet. Public Health 50:105-111.

Bannerman, D. D., M. J. Paape, J. W. Lee, X. Zhao, J. C. Hope, and P. Rainard. 2004. Escherichia coli and Staphylococcus aureus elicit differential innate immune responses following intramammary infection. Clin. Diagn. Lab. Immunol. 11:463-472.

Baumert, A., R. M. Bruckmaier, and O. Wellnitz. 2009. Cell population, viability, and some key immunomodulatory molecules in different milk somatic cell samples in dairy cows. J. Dairy Res. $76: 356-364$.

Blum, J. W., H. Dosogne, D. Hoeben, F. Vangroenweghe, H. M. Hammon, R. M. Bruckmaier, and C. Burvenich. 2000. Tumor necrosis factor-alpha and nitrite/nitrate responses during acute mastitis induced by Escherichia coli infection and endotoxin in dairy cows. Domest. Anim. Endocrinol. 19:223-235.

Dinarello, C. A. 1996a. Biologic basis for interleukin-1 in disease. Blood 87:2095-2147.

Dinarello, C. A. 1996b. Cytokines as mediators in the pathogenesis of septic shock. Curr. Top. Microbiol. Immunol. 216:133-165.

Dulay, A. T., C. S. Buhimschi, G. Zhao, E. A. Oliver, A. Mbele, S. Jing, and I. A. Buhimschi. 2009. Soluble TLR2 is present in human amniotic fluid and modulates the intraamniotic inflammatory response to infection. J. Immunol. 182:7244-7253.

Durieux, J.-J., N. Vita, O. Popescu, F. Guette, J. Calzada-Wack, R. Munker, R. E. Schmidt, J. Lupker, P. Ferrara, H. W. Löms ZieglerHeitbrock, and M. O. Labeta. 1994. The two soluble forms of the lipopolysaccharide receptor, CD14: Characterization and release by normal human monocytes. Eur. J. Immunol. 24:2006-2012.

Eberhart, R. J. 1984. Coliform mastitis. Vet. Clin. North Am. Large Anim. Pract. 6:287-300.

Eckersall, P. D., F. J. Young, C. McComb, C. J. Hogarth, S. Safi, A Weber, T. McDonald, A. M. Nolan, and J. L. Fitzpatrick. 2001. Acute phase proteins in serum and milk from dairy cows with clinical mastitis. Vet. Rec. 148:35-41.

Goldammer, T., H. Zerbe, A. Molenaar, H. J. Schuberth, R. M. Brunner, S. R. Kata, and H. M. Seyfert. 2004. Mastitis increases mammary mRNA abundance of beta-defensin 5, toll-like-receptor 2 (TLR2), and TLR4 but not TLR9 in cattle. Clin. Diagn. Lab. Immunol. 11:174-185.

Griesbeck-Zilch, B., H. H. Meyer, C. H. Kuhn, M. Schwerin, and O. Wellnitz. 2008. Staphylococcus aureus and Escherichia coli cause deviating expression profiles of cytokines and lactoferrin messenger ribonucleic acid in mammary epithelial cells. J. Dairy Sci. 91:2215-2224.

Grönlund, U., C. Hallen Sandgren, and K. Persson Waller. 2005. Haptoglobin and serum amyloid A in milk from dairy cows with chronic sub-clinical mastitis. Vet. Res. 36:191-198.

Hagiwara, K., H. Yamanaka, K. Hisaeda, S. Taharaguchi, R. Kirisawa, and H. Iwai. 2001. Concentrations of IL-6 in serum and whey from healthy and mastitic cows. Vet. Res. Commun. 25:99-108. 
Hallman, M., M. Ramet, and R. A. Ezekowitz. 2001. Toll-like receptors as sensors of pathogens. Pediatr. Res. 50:315-321.

Hirvonen, J., K. Eklund, A. M. Teppo, G. Huszenicza, M. Kulcsar, H. Saloniemi, and S. Pÿorälä. 1999. Acute phase response in dairy cows with experimentally induced Escherichia coli mastitis. Acta Vet. Scand. 40:35-46.

Hoeben, D., C. Burvenich, E. Trevisi, G. Bertoni, J. Hamann, R. M. Bruckmaier, and J. W. Blum. 2000. Role of endotoxin and TNFalpha in the pathogenesis of experimentally induced coliform mastitis in periparturient cows. J. Dairy Res. 67:503-514.

Hoffmann, J. A., F. C. Kafatos, C. A. Janeway, and R. A. Ezekowitz. 1999. Phylogenetic perspectives in innate immunity. Science 284:1313-1318.

Hyakushima, N., H. Mitsuzawa, C. Nishitani, H. Sano, K. Kuronuma, M. Konishi, T. Himi, K. Miyake, and Y. Kuroki. 2004. Interaction of soluble form of recombinant extracellular TLR4 domain with MD-2 enables lipopolysaccharide binding and attenuates TLR4mediated signaling. J. Immunol. 173:6949-6954.

Ibeagha-Awemu, E. M., J. W. Lee, A. E. Ibeagha, D. D. Bannerman, M. J. Paape, and X. Zhao. 2008. Bacterial lipopolysaccharide induces increased expression of toll-like receptor (TLR) 4 and downstream TLR signaling molecules in bovine mammary epithelial cells. Vet. Res. 39:11.

Iwami, K. I., T. Matsuguchi, A. Masuda, T. Kikuchi, T. Musikacharoen, and Y. Yoshikai. 2000. Cutting edge: Naturally occurring soluble form of mouse Toll-like receptor 4 inhibits lipopolysaccharide signaling. J. Immunol. 165:6682-6686.

Kobayashi, Y. 2008. The role of chemokines in neutrophil biology. Front. Biosci. 13:2400-2407.

Koj, A. 1996. Initiation of acute phase response and synthesis of cytokines. Biochim. Biophys. Acta 1317:84-94.

Kurt-Jones, E. A., L. Mandell, C. Whitney, A. Padgett, K. Gosselin, P. E. Newburger, and R. W. Finberg. 2002. Role of toll-like receptor 2 (TLR2) in neutrophil activation: GM-CSF enhances TLR2 expression and TLR2-mediated interleukin 8 responses in neutrophils. Blood 100:1860-1868.

Lahouassa, H., E. Moussay, P. Rainard, and C. Riollet. 2007. Differential cytokine and chemokine responses of bovine mammary epithelial cells to Staphylococcus aureus and Escherichia coli. Cytokine 38:12-21.

LeBouder, E., J. E. Rey-Nores, N. K. Rushmere, M. Grigorov, S. D. Lawn, M. Affolter, G. E. Griffin, P. Ferrara, E. J. Schiffrin, B. P. Morgan, and M. O. Labeta. 2003. Soluble forms of Toll-like receptor (TLR) 2 capable of modulating TLR2 signaling are present in human plasma and breast milk. J. Immunol. 171:6680-6689.

Lee, J. W., D. D. Bannerman, M. J. Paape, M. K. Huang, and X. Zhao. 2006. Characterization of cytokine expression in milk somatic cells during intramammary infections with Escherichia coli or Staphylococcus aureus by real-time PCR. Vet. Res. 37:219-229.

Livak, K. J., and T. D. Schmittgen. 2001. Analysis of relative gene expression data using real-time quantitative PCR and the 2(-Delta Delta C(T)) method. Methods 25:402-408.

McClenahan, D. J., J. P. Sotos, and C. J. Czuprynski. 2005. Cytokine response of bovine mammary gland epithelial cells to Escherichia coli, coliform culture filtrate, or lipopolysaccharide. Am. J. Vet. Res. 66:1590-1597.

Moshage, H. 1997. Cytokines and the hepatic acute phase response. J Pathol. 181:257-266.

Nielsen, B. H., S. Jacobsen, P. H. Andersen, T. A. Niewold, and P. M. Heegaard. 2004. Acute phase protein concentrations in serum and milk from healthy cows, cows with clinical mastitis and cows with extramammary inflammatory conditions. Vet. Rec. 154:361-365.

Papanicolaou, D. A., R. L. Wilder, S. C. Manolagas, and G. P. Chrousos. 1998. The pathophysiologic roles of interleukin-6 in human disease. Ann. Intern. Med. 128:127-137.

Pareek, R., O. Wellnitz, R. Van Dorp, J. Burton, and D. Kerr. 2005. Immunorelevant gene expression in LPS-challenged bovine mammary epithelial cells. J. Appl. Genet. 46:171-177.

Peli, A., A. Scagliarini, D. Britti, and A. Boari. 2003. Detection of proinflammatory and regulatory cytokines in bovine milk using RT-PCR. Vet. Res. Commun. 27(Suppl. 1):779-781.
Petzl, W., H. Zerbe, J. Gunther, W. Yang, H. M. Seyfert, G. Nurnberg, and H. J. Schuberth. 2008. Escherichia coli, but not Staphylococcus aureus triggers an early increased expression of factors contributing to the innate immune defense in the udder of the cow. Vet. Res. 39:18.

Pruitt, J. H., E. M. Copeland, and L. L. Moldawer. 1995. Interleukin-1 and interleukin-1 antagonism in sepsis, systemic inflammatory response syndrome, and septic shock. Shock 3:235-251.

Rainard, P., and C. Riollet. 2006. Innate immunity of the bovine mammary gland. Vet. Res. 37:369-400.

Riollet, C., P. Rainard, and B. Poutrel. 2001. Cell subpopulations and cytokine expression in cow milk in response to chronic Staphylococcus aureus infection. J. Dairy Sci. 84:1077-1084.

Seegers, H. C., V. C. Hood, B. L. Kidd, S. C. Cruwys, and D. A. Walsh. 2003. Enhancement of angiogenesis by endogenous substance $\mathrm{P}$ release and neurokinin-1 receptors during neurogenic inflammation. J. Pharmacol. Exp. Ther. 306:8-12.

Srinivasan, M., K. N. Kodumudi, and S. L. Zunt. 2008. Soluble CD14 and toll-like receptor- 2 are potential salivary biomarkers for oral lichen planus and burning mouth syndrome. Clin. Immunol. 126:31-37.

Strandberg, Y., C. Gray, T. Vuocolo, L. Donaldson, M. Broadway, and R. Tellam. 2005. Lipopolysaccharide and lipoteichoic acid induce different innate immune responses in bovine mammary epithelial cells. Cytokine 31:72-86.

Suffredini, A. F., G. Fantuzzi, R. Badolato, J. J. Oppenheim, and N. P. O'Grady. 1999. New insights into the biology of the acute phase response. J. Clin. Immunol. 19:203-214.

Thijs, L. G., A. B. Groeneveld, and C. E. Hack. 1996. Multiple organ failure in septic shock. Curr. Top. Microbiol. Immunol. 216:209237.

Uthaisangsook, S., N. K. Day, S. L. Bahna, R. A. Good, and S. Haraguchi. 2002. Innate immunity and its role against infections. Ann. Allergy Asthma Immunol. 88:253-264.

van der Poll, T., and S. F. Lowry. 1995. Tumor necrosis factor in sepsis: Mediator of multiple organ failure or essential part of host defense? Shock 3:1-12.

Vangroenweghe, F., L. Duchateau, P. Boutet, P. Lekeux, P. Rainard, M. J. Paape, and C. Burvenich. 2005. Effect of carprofen treatment following experimentally induced Escherichia coli mastitis in primiparous cows. J. Dairy Sci. 88:2361-2376.

Vangroenweghe, F., L. Duchateau, and C. Burvenich. 2004. Moderate inflammatory reaction during experimental Escherichia coli mastitis in primiparous cows. J. Dairy Sci. 87:886-895.

Werling, D., J. Piercy, and T. J. Coffey. 2006. Expression of TOLLlike receptors (TLR) by bovine antigen-presenting cells-potential role in pathogen discrimination? Vet. Immunol. Immunopathol. $112: 2-11$.

Wilson, D. J., R. N. Gonzalez, and H. H. Das. 1997. Bovine mastitis pathogens in New York and Pennsylvania: Prevalence and effects on somatic cell count and milk production. J. Dairy Sci 80:2592-2598.

Yang, W., H. Zerbe, W. Petzl, R. M. Brunner, J. Gunther, C. Draing, S. von Aulock, H. J. Schuberth, and H. M. Seyfert. 2008. Bovine TLR2 and TLR4 properly transduce signals from Staphylococcus aureus and $E$. coli, but $S$. aureus fails to both activate NF-kappaB in mammary epithelial cells and to quickly induce TNFalpha and interleukin-8 (CXCL8) expression in the udder. Mol. Immunol. 45:1385-1397.

Zhen, Y. H., L. J. Jin, J. Guo, X. Y. Li, Y. N. Lu, J. Chen, and Y P. Xu. 2008. Characterization of specific egg yolk immunoglobulin (IgY) against mastitis-causing Escherichia coli. Vet. Microbiol. 130:126-133.

Zunt, S. L., L. V. Burton, L. I. Goldblatt, E. E. Dobbins, and M. Srinivasan. 2009. Soluble forms of Toll-like receptor 4 are present in human saliva and modulate tumour necrosis factor-alpha secretion by macrophage-like cells. Clin. Exp. Immunol. 156:285-293. 